Vasvári, Louise O. "The Yellow Star and Everyday Life under Exceptional Circumstances: Diaries of 1944-1945

Budapest." Hungarian Cultural Studies. e-Journal of the American Hungarian Educators Association, Volume 9

(2016) DOI: 10.5195/ahea.2016.260

\title{
The Yellow Star and Everyday Life under Exceptional Circumstances: Diaries of 1944-1945 Budapest ${ }^{1}$
}

\section{Louise O. Vasvári}

\begin{abstract}
In this article, a follow-up of her 2014 contribution in this journal on Hungarian women's Holocaust diaries, Vasvári discusses six war diaries from 1944-45, which until recently lay forgotten in archives or in private hands. Two of the diaries are by Jewish victims, Dévényi Sándorné, Anna, and Jenő Lévai, who describe their persecution, while the others are by one cleric, Pius István Zimándi, and by three gentile women of various backgrounds, Dr. Mária Mádi, Klára Szebeny, and Mrs. Miklós Horthy. Mádi, who kept the longest diary among all five diarists, from 1941 to 1945 , consistently condemned the political situation in Hungary, before and after the Nazi occupation, while Zimándi did not. Szebeny wrote only about the period after December 1944, when she and her children were trapped in Buda during the siege of Budapest, and Mrs. Horthy avoided all comment about what happened in Hungary before her family was taken prisoner by the Nazis in November 1944 and subsequently kept under house arrest in Germany.

This is a correction to the original article. For information about the changes made, please see the erratum http://dx.doi.org/10.5195/ahea.2017.273
\end{abstract}

Keywords: Hungarian Holocaust, life writing and war, gendered life writing, war diary

Biography: Louise O. Vasvári (MA and PhD, UC Berkeley) is Professor Emerita of Comparative Literature and of Linguistics at Stony Brook University. Currently she teaches in the Linguistics Department at NYU and is also Affiliated Professor at the University of Szeged. She works in Medieval Studies, diachronic and socio-linguistics, Holocaust Studies, and Hungarian Studies, all informed by gender theory within a broader framework of comparative cultural studies. In relation to Holocaust Studies she has published with Steven Tötösy, Imre Kertész and Holocaust Literature (2005), Comparative Central European Holocaust Studies (2009), and Comparative Hungarian Cultural Studies (2011).

A Special Cluster, "Seventy Years On, 1944-2014," in Volume 7(2014) of this journal featured five articles dealing with life writing about World War II Hungary. In my own contribution (Vasvári 2014) I discussed a number of women's diaries from the period, to which

${ }^{1}$ This study was prepared with the support of a 2015-2016 Senior Core Fellowship from the Institute of Advanced Studies of the Central European University in Budapest.

(cc) $\mathrm{Br}$

ULIS D-Serke
New articles in this journal are licensed under a Creative Commons Attribution 4.0 International License.

This journal is published by the University Library System of the University of Pittsburgh as part of its D-Scribe Digital Publishing Program and is cosponsored by the University of Pittsburgh Press 
Vasvári, Louise O. "The Yellow Star and Everyday Life under Exceptional Circumstances: Diaries of 1944-1945 Budapest." Hungarian Cultural Studies. e-Journal of the American Hungarian Educators Association, Volume 9 (2016) DOI: 10.5195/ahea.2016.260

this article is meant to serve as an addendum. Perhaps surprisingly, since the time of that article several unique additional diaries from 1944-1945 have appeared, which until now lay forgotten in archives or in private hands. Of these, I will discuss the diaries of two Jewish victims of persecution, Ann, Dévényi Sándorné and Jenő Lévai, briefly contrasting them with the diaries of a canon, Pius István Zimándi, and three gentile women of different backgrounds, Dr. Mária Mádi, Klára Szebeny, and Mrs. Miklós Horthy (compare also the study in this issue by Maya LoBello on the wartime diary of Miksa Fenyő). Mádi, who kept the longest diary among all five diarists, from 1941 to 1945, consistently condemned the political situation, before and after the Nazi occupation, while Szebeny was only concerned with the period from December 1944, when she and her young children were trapped in Buda during the siege of Budapest, and Mrs. Horthy avoided any comment at all about what happened in Hungary and wrote only about the family's life under house arrest in Germany from November 1944.

When the Germans entered Hungary on March 19, 1944, Dévényi Sándorné was a thirtytwo year old married Jewish woman in the fifth month of pregnancy and with a thirteen-year old son, while Jenő Lévai, aged fifty-two, was a man with broad experience as a political observer, having served in World War I and been a prisoner of war in Siberia, from where he had managed to escape and had subsequently become a renowned newspaperman and newspaper owner during the interwar Horthy regime. Both Dévényiné and Lévai were middle-class assimilated Jews who were victims of prosecution and thus had to undertake desperate strategies for survival. Mádi, the same age as Lévai, was a gentile doctor who wrote her diary in English both as a way of safeguarding its contents and out of the hope that after the war her family in the United States would be able to read it. Szebeny wrote her diary in the form of letters to her husband, who was in the army and whose whereabouts she did not know. Mrs. Horthy, writing while in German custody, avoided writing about all but the most personal concerns. My aim here is to illustrate briefly the varying "voices" of these narrators telling of their subjective personal experiences; that is, as self-historians documenting their own lives in confrontation with catastrophic historical circumstances. By studying these and other wartime diaries I want to illustrate how recovering individual fragmentary histories can help reconstruct the experience of everyday life in wartime from the micro-historical vantage point of the writers, who could not know how the events around them would end, as well as to shed light on their day-to-day personal experiences in ways that formal historical documents cannot.

In my earlier article I presented a brief overview of the very discipline-driven scholarly disagreements about the legitimacy of forms of life writing as historical sources. While I do not want to repeat that discussion here, it is perhaps useful to add a reference to Jeremy D. Popkin's (2005: 4) view that while history and life writing both claim to tell true stories about the pastand while historians have traditionally rejected first-person accounts as subjective and therefore unreliable - the two discourses are better considered as two different, complementing ways of narrating and preserving the past. Precisely because an enormous amount of historical documentation has been written about what happened but relatively little about what was experienced and felt by victims of war it is of interest to analyze life writing. My own interest in wartime life writing, and in Hungarian World War II diaries specifically, is less concerned about unearthing new facts - although important new facts inevitably do emerge from life writing - as about documenting the internal lives of the diarists. As Berel Lang (2005: 118) has discussed, the most memorable diarists are recalled for what they wrote rather than for the independent importance of the events they describe, since writers' responses are uniquely their own in a way 
Vasvári, Louise O. "The Yellow Star and Everyday Life under Exceptional Circumstances: Diaries of 1944-1945 Budapest." Hungarian Cultural Studies. e-Journal of the American Hungarian Educators Association, Volume 9 (2016) DOI: 10.5195/ahea.2016.260

that the events are not. In other words, the first person point of view in wartime diaries allows us some access to the conscious experiences of diarists - their judgments, perceptions, and emotions - and can thus help us gain an increased understanding of human experiences and human motives during a time of historical cataclysm. Traditionally diaries have been studied as documents for information about the writer's life and times but not as a therapeutic tool, yet diary writing itself can serve as a form of survival mechanism for the diarists themselves, as is well documented, for example, in the diaries that emerged from the Jewish ghettos of World War II. It is diaries that can offer the most personal and immediate documentation of day-to-day events; even in the midst of horrible events the diarists may shed unique light on details of their daily lives, or disclose their sometimes idealistic and naïve perceptions of reality, as well as information about social structures and relationships around them.

I stated that I want to utilize wartime diaries to study fragments of the emotional life of wartime diarists, but I should add that my additional aim, from a combined cultural studies and micro-historical methodology, is to retrieve significant "voices," especially of female narrators, and contrasting voices from different religious and social backgrounds, as cultural witnesses of their subjective personal experiences as seen from the center of historical events through their parahistorical life writing. Although the term parahistorical may sound unnecessarily technical, it means, more simply, a portrayal of self in history, where the autobiographer is the self-historian. It is often the very ordinariness of personal life stories of individuals looking upon historically traumatic events as they transpire around them that makes such writing meaningful, not a topdown summary recorded by historians (cf. Fulbrook and Rublack 2010: 25-27).

Four of the six diaries considered here are by females, and it is worth noting that feminist researchers have explored the connection between women's writing and "dailyness," that is, the connection between women's writing and the fragmentary pattern of their daily routines, including/as well as the recovery and validation of women's voices through the domestic everyday, thus envisioning the diary as one form of women's autobiographical writing (Huff and Bunkers 1996: 6, Hogan 2008: 95). Feminist and gender studies have broadened the historical as well as methodological analysis of the Holocaust by introducing the perspective of the individuals through the integration of personal documentation, such as letters, post-Holocaust memoirs, and oral history into the historical narrative (Ofer 2011: 8). At the same time, feminist historians have begun to focus specifically on Jewish family life during Nazism, and with particular emphasis on the lives of wives and mothers. In her groundbreaking Between Dignity and Despair: Jewish Life in Nazi Germany (1998), Marion A. Kaplan, drawing on diaries, letters, and other contemporary documents, studied how Jewish families managed their daily lives in 1930s Germany while facing ever increasing social, economic, and psychological hardships as they lost their livelihoods, possessions, and eventually their homes; on the part of the perpetrators, all these steps were meant to be a form of progressive social death preceding the victims' physical destruction. Well aware that Holocaust history has tended to treat the male experience as the universal experience, Kaplan paid particular attention to the plight of women, as it was women who kept up the rhythm of daily life and were at the same time forced to take on new roles as heads of their families in wartime. Compare also Esther Herzog's (2009: 2) study on how Nazi Germany's attack on Jewish parenthood broke down the separation between the public and private in order to dehumanize the victims. Herzog also traced how parents stripped of their livelihood, property, and civil rights went through a process of "infantilization," during and after which neither they nor their children had any legal rights. During this period of 
Vasvári, Louise O. "The Yellow Star and Everyday Life under Exceptional Circumstances: Diaries of 1944-1945 Budapest." Hungarian Cultural Studies. e-Journal of the American Hungarian Educators Association, Volume 9 (2016) DOI: 10.5195/ahea.2016.260

ruptured frameworks new gendered divisions of power and family roles emerged, in which women's strength and adaptability helped them create new family-frameworks and make decisions under life-threating situations.

While the studies I describe above about the lives of Jewish women and Jewish families during Nazi persecution were based on case studies of Nazi Germany, Dévényiné's diary, Kismama sárga csillaggal ['Mother-in-Waiting with Yellow Star'] is an important contribution to the history of the family life of persecuted Budapest Jews during 1944-45 (see Huhák, Szécsényi, and Szívos's edition, which provides an excellent Introduction and notes; see also Szívós 2014, where the author is still identified by a pseudonym, while in the published diary the author's daughter gave permission for her mother's name to be used). The diary is the accounting of the day-to-day-struggles of a woman with a thirteen-year old son and five months pregnant with her second child when the Germans occupy Hungary on March 19, 1945. Hitler, prompted by concern that Admiral Horthy was trying to extricate Hungary from the war, occupied its ally sending a small group of SS troops under the command of Eichmann. Dévényiné reports in her diary not only about what happens day by day to the Jews, who are subjected to constant new regulations, the wearing of the Star of David, having to move into so-called csillagos házak ['[Yellow] Star houses'], and ultimately to try to go into hiding, but also about the reaction of non-Jews around them to their situation. What we see is not only a woman's point of view and experience, but also a very unusual one in that as a pregnant woman, who after her husband is called into munkaszolgálat ['labor service'] has to cope with all decision-making and all hardships by herself. Her aim through the continuing months, when she and her family are in mortal danger, is to survive to give birth to her newborn daughter and keep her alive, as well as protect her son, and also to try to help her parents and four siblings, all the while dealing with innumerable crises as one after another anti-Jewish regulations are implemented. Dévényiné starts her diary on March 20, the day after the Sunday morning occupation of Hungary by the Germans. She writes that she had planned a major cleaning for that day but then left it to the cleaning woman. Through the subsequent days, when she writes daily, her initial preoccupations include having a loose-fitting dress made for her pregnancy, visiting her hospitalized mother and various other relatives, and having her teeth fixed, all in preparation for worse times to come. She argues a lot with her husband, while he is still around, who tells her then and on several subsequent occasions that they should prepare by obtaining some poison.

Dévényiné reports that her sister-in-law Regina was the first person she saw with the yellow star, and soon after, on April 4, when she sews one onto her own clothes she comments: "I am not ashamed but instead I find it to be ridiculous" [nem szégyelem magamat, inkább nevetségesnek tartom] (32). Yet, when she reports on her first outing with the star on her coat it is clear she also feels demeaned:

On the streetcar I don't dare to sit down, on the platform I stand with my back to people and look out at the street. I look at the people. How many are wearing the star and how many of them look miserable. It is very demeaning, and yet they still look ridiculous with that yellow patch. As if children and not adults had invented it.

[A villamoson nem merek leülni, a peronon háttal állok az embereknek, úgy nézek ki az utcára. Nézem az embereket. Milyen sokan járnak csillaggal, mennyi a 
Vasvári, Louise O. "The Yellow Star and Everyday Life under Exceptional Circumstances: Diaries of 1944-1945 Budapest." Hungarian Cultural Studies. e-Journal of the American Hungarian Educators Association, Volume 9 (2016) DOI: 10.5195/ahea.2016.260

szegény kinézésü ember közülük. Nagyon megszégyenitő, és mégis nevetségesen néznek ki ezzel a sárga folttal. Mintha nem is felnöttek, hanem gyerekek találták volna ki.]

On April 11, her son's thirteenth birthday Dévényiné insists on making a birthday party for him, while her husband, who has gotten his orders to report for labor service informs her he has bought the poison he was recommending. On May 4, when the wearing of the Yellow Star has already been in effect for a month, Dévényiné realizes one day how even a friend who had been helping her carry packages is very uncomfortable being seen with her and also reports on how, even pregnant, but wearing the star, she was insulted on a streetcar:

When we went down to the street I didn't know why he seemed so uneasy. Only later did I realize that I was wearing the Yellow Star, and I sent him on ahead. It is awful how embarrassed he is to be seen with me. Yesterday I was also demeaned, and I still get red with anger when I think about it. On the streetcar when a woman gave me her seat, two other women piped up: look, how important it is for a Jew to get to sit down. I asked didn't she [sic] see that I am pregnant, and she replied, so what, you're a Jew! I was waiting for someone to say something but even the woman who had given me her seat turned her head away. I could barely stand it until I could get off the streetcar (51-51).

[Mikor együtt mentünk le az utcára, nem tudtam miért van olyan zavarban, csak aztán jutott eszembe, hogy rajtam csillag van, elöreküldtem öt. Rémes hogy szégyell velem menni. Tegnap is megszégyenitettek, még most is vér szökik az arcomba ha rágondolok. A villamoson egy nö átadta a helyét nekem, két nö megszólalt: nézd, milyen fontos, hogy a zsidó leüljön. Azt kérdeztem, nem látje-e hogy állapotos vagyok, azt felelte, na és, de zsidó! Vártam, hogy valaki szólni fog mellettem, de még az a nö is, aki átadta a helyét, elforditotta a fejét. Alig vártam, hogy lenn legyek a villamosról.]

In early June, when she is six to eight weeks away from delivery Dévényiné reports that she is very angry when people criticize her decision to bear a child as if she were a megesett lány ['unwed mother']. When a doctor tells her she should induce early delivery before things get worse, she refuses, saying "I won't do it. I want this child at all cost” [nem teszem meg. Én minden áron akarom ezt a gyereket] (67). When she is running around, trying to find an apartment to exchange with a Christian so she can move into a building that has been designated as a yellow-star house she laments that all she would be able to exchange for her beautiful apartment on the Danube waterfront would be "two dark holes located in the courtyard" [két sötét udvari lukat] (70). She also bemoans being forced to abandon her cherished belongings, the trappings of her middle-class life that she has for so long worked and struggled to acquire. And as she is struggling with endless additional crushing daily preoccupations, like finding movers who will help move her to the ghetto, she sees advertisements for trips to the Balaton and for other amusements, and laments that "for Christians to frequent coffeehouses is not considered parasitical" [kereszténynek kávéházba járni nem parazitáskodás] (79). 
Vasvári, Louise O. "The Yellow Star and Everyday Life under Exceptional Circumstances: Diaries of 1944-1945 Budapest." Hungarian Cultural Studies. e-Journal of the American Hungarian Educators Association, Volume 9 (2016) DOI: 10.5195/ahea.2016.260

By June 30 Dévényiné is aware that in the whole country outside of Budapest deportations of Jews have been completed and wonders if it will soon be the turn of Budapest Jews. In August she manages to get a Swedish Letter of Protection or Schutzpass for her family, which allows her to circulate without a yellow star, and for a time she hopes that this will also keep them from being deported. The following week she joins scores of others in the vain attempt to convert with the hope that this will save them from deportation, but she feels it is her duty to tell the deacon who christens her that she is not doing it from belief. Subsequently her life becomes increasingly difficult, and in the midst of many unspeakable difficulties on July 19 she gives birth to her daughter, Juditka. She writes "nothing beyond the child matters to me" [nem érdekel a gyereken kivül semmi] (93), and from then through the following months, through the ever increasing terror, the diary continues with incredible details of seeking refuge in a cloister with other mothers with babies, including attempts to feed the infant and wash and dry the table napkins she is using as diapers.

Dévényiné 's husband, who very fortunately is stationed in a labor camp nearby, manages to appear briefly from time to time but has no attachment to the child because, Dévényiné thinks, he didn't go through the pregnancy with her. When in October 1944 Ferenc Szállasy and his fascist Arrow Cross Party oust Miklós Horthy and take over the government, her husband once again suggests that they take poison, but she herself finds the force to continue the struggle to survive through her single-minded devotion to her daughter: "I adore Little Judit with such protectiveness that it is not good. I still can't believe the miracle that I have her" [Juditkát olyan féltéssel imádom hogy ez már nem jó. Még mindig nem tudok betelni avval a csodával hogy ö nekem van] (97). Dévényiné and her nuclear family survive, as does her father, but her mother dies in the ghetto and all four of her siblings, two sisters in Bergen Belsen and two brothers in labor service, are deported and none return. Dévényiné's diary is an extraordinary document that shows how a mother sustained her family's life despite the chaos and brutality of being hunted victims. Lenore L. Weitzman and Dalia Ofer suggest viewing the family strategy of survivalthe very attempt to go on living regardless of the hardship - as one manifestation of resistance, just as important as other forms of resistance, such as membership in an underground movement or participation in armed activities.

It is one of the editors of Kismama sárga csillaggal, Erika Szívos, who initially found a typed version of Dévényiné's diary in the Holocaust Documentary Center in Páva Utca in Budapest, which had been bequeathed to the Center in 2013 by Dévényiné's daughter Judit. It is a reconstructed diary, as Dévényiné typed it in the summer or fall of 1945 while the original no longer exists. There is, therefore, no way to ascertain what she might have deleted, and occasionally there are signs of details she could have only added with hindsight. Dévényiné's diary could best be read alongside the diary of Borbála Szabó (1920-1975), which I discussed in my 2014 article in this journal. While Dévényiné's diary starts in March 1944 with the words bejöttek a németek ['the Germans have invaded'], Szabó's diary, although very detailed, starts only on October 18, 1944, and describes only the last months of World War II in Budapest, after her fiancé, Lajos Krausz, was captured and deported in November 1944 during the Arrow Cross takeover. Szabó wrote about daily life in the Budapest ghetto for her deported fiancée, so he could read it after the war, but she was never to see him again. She herself was conscripted for a woman's labor service unit, an experience she lived through along with three close friends. She describes the last days of World War II, which the four of them survived, but Lajos was murdered in Bergen Belsen. Throughout her diary Szabó writes in an "I am a camera" mode and, 
Vasvári, Louise O. "The Yellow Star and Everyday Life under Exceptional Circumstances: Diaries of 1944-1945 Budapest." Hungarian Cultural Studies. e-Journal of the American Hungarian Educators Association, Volume 9 (2016) DOI: 10.5195/ahea.2016.260

amazingly, in spite of her fluctuating feelings, she seems to keep faith and hope alive. Szabó's diary was published only in 1982 by her daughter (see excerpts and photos from Szabó's Hungarian text in "Budapesti napló" at: www.yadvashem.org, as well as the important excerpts published by Borbála's niece, Vera Szabó 2009). Unfortunately, to date only Hungarian readers who can read the full text are able to get a real sense of the strength and amazing optimism of Szabó's personality and begin to understand the incredible level of escalating terror through which she had to struggle to survive as well as help both her mother and her fiancé's parents survive.

If Dévényiné and Szabó's diaries are primarily Holocaust family chronicles that provide Budapest tableaux of Jewish everyday life and fighting for survival in 1944-1945, Jenő Lévai's (1892-1983) “...Csak ember kezébe ne essem én...”-Deportácio, Télach [“May I Not Fall Into the Hands of My Fellow Man': Deportation, Leaving, Letter of Protection'] is at one and the same time a personal diary, a historiographical documentary work, and a sociologicalpsychological study, in which Lévai never ceases to be a social observer, even when describing events in which he was himself a victim. Ferenc Laczó (2015) reviews Lévai's career as the first chronicler of Hungarian Holocaust historiography, whose most productive period was in the immediate postwar years, when he wrote almost a dozen works until 1948, after which time he was no longer allowed to write. In spite of his enormous contribution Lévai remains unknown outside of Hungary and even within Hungary he is known only by specialists in the field and attacked by some for what they consider his strongly ideological journalistic writing. In his postwar writings Lévai argued that the Germans, arriving with only a force of three hundred men, could never have managed to implement the deportations without the brutal work of the Hungarian police and gendarmerie. He also praised Horthy for halting deportation in early July 1944, yet pointed out that the fact that he had this power meant that he could be held responsible for the deportations that took place from March to that time. As a journalistic-historian Lévai wrote mostly about what he himself had personally experienced, much of which is recorded in his diary, which he finished in January 1945, but which for unknown reasons he never published. The diary is in the fullest sense of the word a documentary diary, as it includes contemporary documents, newspaper clippings, and political leaflets, some of which have probably survived only in Lévai's collection. A useful introduction provides an overview of Lévai's difficult but very adventurous life, which included five years as a prisoner of World War I in Siberia, from which he managed to escape in 1920, only to encounter untold further problems in establishing himself as a journalist in interwar Hungary. It is not known how amid hiding and during bombings he managed to collect all this material, nor is it known where he was able to leave it for safekeeping. Lévai's widow gave the original of his diary to the Magyar Tudományos Akadémia (MTA) ['Hungarian Academy of Sciences'], where it just languished in paper cartons until part of it disappeared. In 1985 Lászó Váradi found it by chance and, realizing its importance, typed the manuscript and put copies of the additional documents into the text, but in the meantime the original manuscript cannot be located, although it may still be in the archives, which still have not been fully research.

Lévai's diary has now been published for the first time by Múlt és Jövö, with the full complicated title of the original, of which the first part is a quote from a Hebrew prayer, the Ta[c]hanun ['Supplication'], while the subtitle consists of three key words, each of capital importance for the persecuted victims: deportácio, from which one might be saved only by télach ['leaving'], or by a Schutzpass ['Letter of Protection'] granted by a foreign power. In his 
Vasvári, Louise O. "The Yellow Star and Everyday Life under Exceptional Circumstances: Diaries of 1944-1945 Budapest." Hungarian Cultural Studies. e-Journal of the American Hungarian Educators Association, Volume 9 (2016) DOI: 10.5195/ahea.2016.260

diary Lévai is very critical of the gentile middle class, some of whom took an active part in killing Jews and many others observed without doing anything, but he also condemns Jews who didn't always behave heroically. Lévai's diary writing was a live project of documenting history as it was happening, but it was also the course of his own fate, of which he could not yet know the outcome. He himself was in constant danger of being killed, was witness to the murder of most of his friends and relatives and to the loss of his property, and he was thrown out of a society to which, especially as a World War I veteran and prisoner of war, he always felt he belonged. His diary can very profitably be read alongside Dévényiné's because the two naturally write about many of the same subjects, but while she writes about her personal struggles he also provides the broader background. For example, as mentioned above, she writes about the horrors of trying to exchange in the period of a few days her beautiful apartment for a minimal place in a house now declared a yellow-star house and about how impossible it is even to find a suddenly very expensive mover and gives a list of the specific items of furniture she finally succeeds in taking with her to the ghetto. Lévai details how hundreds of thousands had to move in a matter of days, which he calls "the largest migration in the history of Budapest" [a Budapest életében a legnagyobb szabásu vándorlás] (170); he details how haulers were charging ten times their usual rate, and in the last hours even twenty times the rate, especially in the fancier hilly areas of Buda. He also appends two pages from the June 16, 1944 issue of the Budapest Magyar Szó ['Hungarian Word'] newspaper, which gives exhaustive details of the yellow-star houses legislation, with twin headlines such as: Meddig kell kiköltözniök a zsidóknak a lakásokbol? ['By when do the Jews have to move out of their apartments?'] and Mikor költözhetnek be a keresztény bérlök a zsidó lakásokba? ['When can Christian tenants move into the Jewish apartments?']. Lévai writes that on March 15 people still think the war will end and Jews think they will make it, so that even on March 19 "[t]he Budapest promenade shines in its usual colorfulness. Even the Second Jewish Law doesn't keep the ladies of Downtown Budapest and of Lipótváros from parading their new spring toilette" [a pesti korzó szokott tavaszi színpompájában tündöklik. A Belvárosi és Lipótvárosi hölgyeket a második zsidótörvény sem akadályozza meg abban, hogy új tavaszi toilettjüket felvonultassák] (14).

An experience common to both genders and, in a sense, to Jews and gentiles alike because seen in the public domain, was the first day of the mandatory wearing of the yellow star by those decreed as Jews. It therefore becomes interesting to see how this scene is described in individual stories from the first person point of view. We have already seen in the above quotes from Dévényiné that she conveys her personal feelings of shame and desperation at the imposition of the yellow star. Lévai, although also affected by the same shameful regulation, at the same time is also able to look at the larger scene and its implications critically, as if standing on the outside:

Five days later, on April 5, Budapest streets scream in yellow. The first days we expect sympathy demonstrations but those don't happen. The capital's Christian society behaves stiffly and without compassion. They avoid those who are stigmatized. Old friendships ceased in one stroke. We were ejected from society. Without a ghetto we were pushed into a social ghetto. It was intolerable. Or at least that's what we thought then... And one after another, new restrictive regulations appear. At the same time one can see signs such as: "we do not serve persons with a yellow star" (22). 
Vasvári, Louise O. "The Yellow Star and Everyday Life under Exceptional Circumstances: Diaries of 1944-1945

Budapest." Hungarian Cultural Studies. e-Journal of the American Hungarian Educators Association, Volume 9 (2016) DOI: 10.5195/ahea.2016.260

[Öt nap mulva, április 5-én, sárga színben rikít a pesti utca. Az elsö napokban szimpátiatüntetést várunk, ám ez elmarad. A föváros keresztény társadalma mereven, feszesen és kegyetlenül viselkedett. Kikerülte a csillaggal megbélyegzetteket. Régi barátságok szünteg meg egy csapásra. Ki voltunk közösítve. Gettó nélküli társadalmi gettóba szorultunk. Kibírhatatlan volt. Legalább is azt hittük még akkor...Egymás után jelennek meg a többi korlátozó rendelkezések is. Ugyanakkor már ilyen feliratokat látni: "sárga csillagos egyéneket nem szolgálunk ki.]

To Dévényiné 's and Lévai's descriptions of how it felt to be a Jew forced to wear the yellow star on April 5, we can compare also an account quoted in Gergely Kunt's article published in our 2014 Seventieth Anniversary cluster from the dairy of thirty-six year old "Margit," who also composed her diary/immediate memoir for her husband who was in labor service. She wrote in an exceptionally ironic style, creating all sorts of verbal games around the term sárga csillag, such as a csillag premierje, the first day the yellow star had to be worn by all those deemed to be Jews by the new ruling, and elcsillagodás ['getting all starry'], i.e., when the yellow star started to be visible everywhere. And, finally, to these reactions of the victims of the shameful legislation we can contrast the photographs and their gleefully nasty captions of the first day of the imposition of the yellow star, published in the Magyar Futár ['Hungarian Dispatch'], an anti-Semitic extreme right-wing illustrated weekly, which by 1944 had some two million readers. The Magyar Futár was founded in 1941 by Ferenc Rajniss, who later became Minister of Religion and Education in the Szállasi government; after the war he was executed as a war criminal. The various photographs, all of Jews wearing the yellow star, carry captions whose composite message is: now that they are required to be identified by the yellow star it can be seen just how many Jews were in the capital who had wanted to seem assimilated [and] for now they wear the star somewhat painfully and in insulted fashion. The page below from the Magyar Futár is from the private files of Stephen P. Casey (b. 1924, as István Katona), whose mother-in-law had kept it because she herself is pictured (marked with an asterisk) (http://isurvived.org/Pictures_iSurvived-2/Hungarian-jews_BW.GIF). 
Vasvári, Louise O. "The Yellow Star and Everyday Life under Exceptional Circumstances: Diaries of 1944-1945 Budapest." Hungarian Cultural Studies. e-Journal of the American Hungarian Educators Association, Volume 9 (2016) DOI: 10.5195/ahea.2016.260

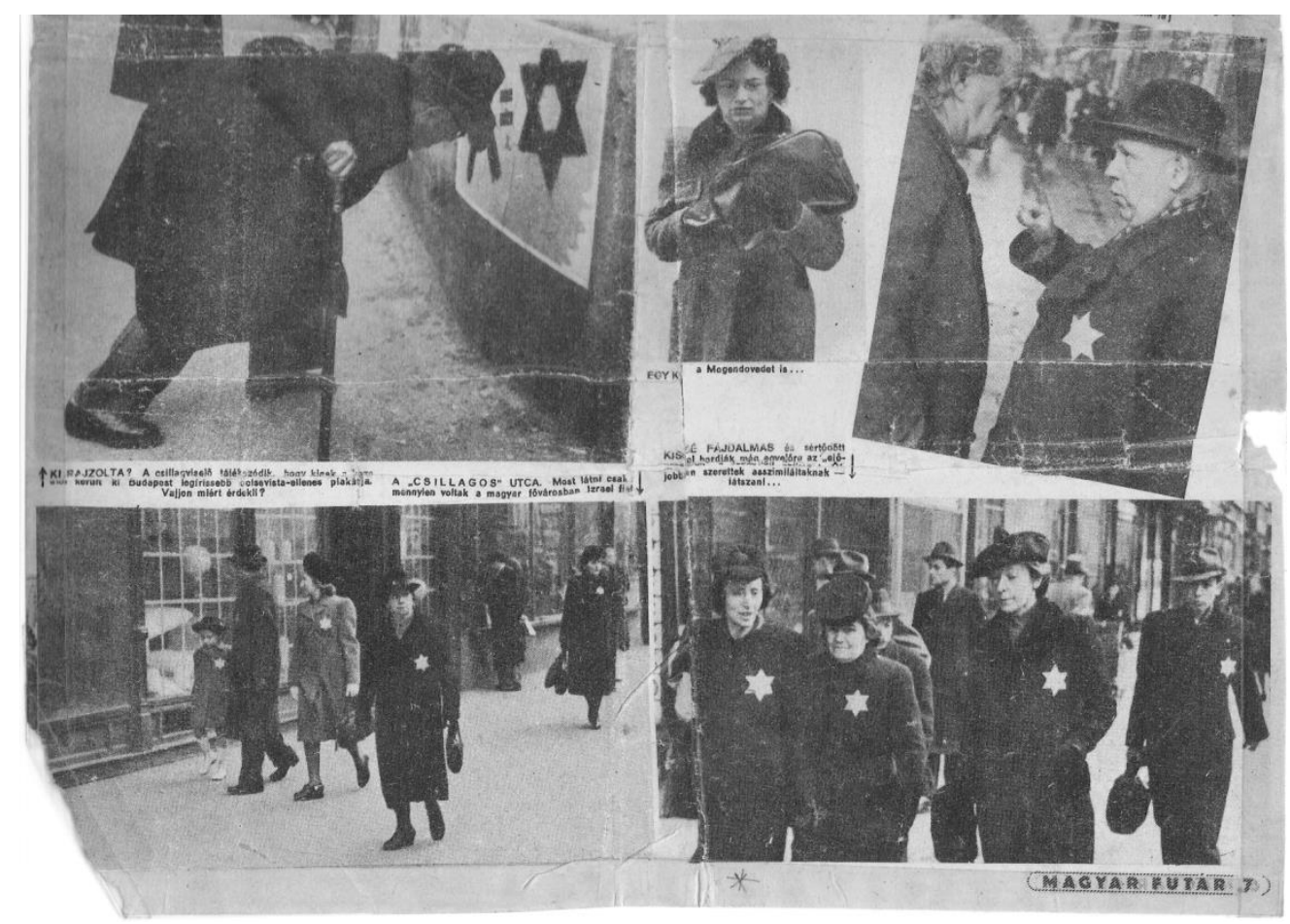

Lévai does not limit his criticism to the indifference of the gentile population to the plight of the Jews and does not shy away from criticizing also those Jews who even just before the October 15 putsch by Ferenc Szállasi still managed to remain protected in Budapest and lived obliviously to the deportation all the Jews outside Budapest and to the plight of their fellow ghettoized Jews and even to dangers facing themselves. He describes how October 15, the beginning of fall, was a beautiful sunny day, and much like the March 15 he described half a year earlier, life on the promenade was still active:

On the Budapest promenade every seat is again taken, the Hangli [a popular restaurant] is again full to bursting. The ladies from Downtown and from Lipótváros are again parading their newest autumn creations. It seems that the crowding in the ghettos still hasn't taken away the zest of some Jewish women from promenading. Naturally on the promenade there are no women to be seen wearing the yellow star but in Váci utca they are already more frequently visible (48).

[A pesti korzó ülöhelyei újra foglaltak, a Hangli megint "pukkadásig” telve. A Belvárosi és Lipótváros hölgyei a legújabb őszi kreációkat újra felvonultatják. A gettobeli tömörülés még mindig úgy látszik, nem vette el kedvét néhány zsidó nőnek a korzózástól. Csillagos nöt természetesen nem látni a korzón, de a Váci utcában már inkább.]

Perhaps the most intimately horrible episode of Lévai's diary (58 ff) is where he describes how, on October 19, several hundred men from sixteen to sixty, including himself, are driven from a yellow-star house and are kept until November 5 on a totally useless work detail, 
Vasvári, Louise O. "The Yellow Star and Everyday Life under Exceptional Circumstances: Diaries of 1944-1945 Budapest." Hungarian Cultural Studies. e-Journal of the American Hungarian Educators Association, Volume 9 (2016) DOI: 10.5195/ahea.2016.260

where they receive no food or accommodation and many are randomly and sadistically killed. In the last part of his diary Lévai also details how everyone was stealing from everyone, first the house superintendents and their helpers, who would steal the belongings of the deported, feeling they had a right to the belongings of "their" Jews so the items "do not fall into the hands of the Arrow Cross men" [ne fusson a nyilasok kezébe]. Then later someone in uniform, perhaps only a postman, would arrive at the building from where some have been already deported to steal more, until finally a German army truck would arrive to take away what was left. On Nov. 15 he writes that he has to observe how his own belongings disappear:

My heart aches as I see my beautiful bedroom set, my bedding, my suitcases. They disappear one after another from the house entryway [as] people are already stealing from one another. From my belongings (98).

[Fájó szívvel látom gyönyörü hálószobámat, ágynemüimet, bőröndjeimet. Egymás után tünnek el a kapu alatt. Már út közben egymást lopják meg. Az én holmijaimból.]

Even some Jews, if they had a chance, stole from sealed apartments of other Jews, so that, as Lévai put it, "the whole of Hungarian society became thieves" [tolvajokká alakul át az egész magyar társadalom] (75). On January 17, with the liberation of the ghetto, thousands, who looked like living dead, ran out, seeking their loved ones and food; at that time, too, the plunder continued, by Christians and Jews alike, by all classes, and of course soon by the occupying Russians. It can well be argued that Lévai is too forgiving for the crimes of the latter, perhaps because he is so thankful for liberation, or because he can measure the level of Russian cruelty and looting only in contrast to the magnitude of what he had previously witnessed:

It serves to the credit of the occupying troops that only individual actions happened, smaller thieveries and robberies and not too frequent forcing $[$ sic $]$ of women (198).

[Az orosz megszálló csapatok becsületére szolgáljon, hogy csak egyéni akciók fordultak elö, kisebb tolvajlások, apróbb rablások és nem túl sürü eröszakodások a nökkel szemben.]

Mária [Kiss] Mádi (1898, Budapest-1970, Houston, Texas) was a highly educated gentile woman who kept a diary between December 1941, when Hungary severed relations with the US in World War II, and September 1945. Born and raised in Budapest, Mádi was a doctor from a gentry background, who attended universities in Britain and earned her medical degree in 1922, specializing in radiology. She married Lajos Felsőbuki, an orthopedist, around 1920 but they divorced in 1924. She had a daughter Hilda, who was born in 1920 and who married George G. Walton, an American geologist and immigrated to Louisiana, where she gave birth to a son and a daughter. Mádi had been planning to join her daughter and her family when the U.S. entered the war and she was trapped in Hungary, and so she began her diaries as a way to "communicate" with her family abroad. She wrote in English, both for safety and because she said that she didn't want her grandchildren, to whom she addressed her diary, to learn Hungarian, even though she 
Vasvári, Louise O. "The Yellow Star and Everyday Life under Exceptional Circumstances: Diaries of 1944-1945 Budapest." Hungarian Cultural Studies. e-Journal of the American Hungarian Educators Association, Volume 9 (2016) DOI: 10.5195/ahea.2016.260

could not know if her daughter would ever get to read her words. By the end of the war Mádi filled sixteen notebooks stating at the beginning of her diary that "I am going to see, hear, to witness everything...it may happen of course that neither myself nor my diary will ever reach you" (n.p.). She did survive the war and was able to emigrate in 1946, became a US citizen in 1952 , and worked in the US as a psychiatrist. Her diaries also contain photos, clipping and correspondence, as well as some annotations she added to them in pencil in 1960. They had been kept in plastic bags in a family safe for thirty years and her grandson Stephen Walton, who donated the diary to the US Holocaust Memorial Museum in March 2013, said that the family hardly ever looked at them. The totality of the diary volumes has recently been posted in its entirety on the Museum's website: http://collections.ushmm.org/search/catalog/irn50967.

In her diary Mádi describes many details of the war, from food prices to the weather and politics, such as the Hungarian propaganda she hears, and writes about missing her daughter and even about her dog, of whom she includes photos in her diary. After March 1944 she describes the constant air raids and many deprivations the city residents suffer; she also writes about everything she sees and hears, including what her Jewish friends are going through. In her entry for April 2, 1944 Mádi refers to the upcoming imposition of the yellow star on some of her friends and describes how one Tercsi néni, a Jewish woman living in a mixed marriage, according to the new rulings will have to wear the yellow star while her husband and children are considered gentile. This was because the March 31 edict on the wearing of the yellow star according to the Nürnberg laws decreed that all Jews from age six had to wear the star, included those who lived in mixed marriages. Mádi tried to console her friend with the rumor that she had heard that there would be changes to the rulings and that in cases like hers, although she would still be considered a Jew, she will not be obliged to wear the yellow star. Mádi then goes on to talk about one Magda Pató, who has only one quarter Jewish blood so that her legal standing is not touched, and yet some people at her work behave very nastily toward her: her boss immediately transfers her from her job of six and a half years to a much worse position, and she also finds a yellow star in her desk drawer. On April 5 Mádi adds: "Jews will have to wear the yellow star from April 5 on. They are sick with shame and fear, marked thus, they may be set out for any brutality." On April 14 she reports:

Every day a new cruelty. Last night 250 Jews and Jewesses were called to work with a rug and a pail and it is believed they will have to work and live close to the targeted areas.

On October 17 Mádi found a friend, Irén Lakos and her seven-year old nephew in her apartment and for four months she sheltered them. The boy's father was deported but survived, but his mother, Rozsa, was killed in Auschwitz. Mádi didn’t much like children and found the spoiled child irritating but she did nurse him when he was ill. She writes about him with mild antiSemitism: "And the best joke is this seven-year old child is the worst type, whom I try hard to save. No bad quality, we used to know as Jewish qualities, is missing." In 2015 Mádi was posthumously named Righteous Among the Nations by Yad Vashem.

The final two diaries I will discuss, by Klára Szebeny and by Mrs. Miklos Horthy, start only in late 1944, so first I include here by way of contrast with Mádi's reaction to the April 5, 1944 imposition of the Yellow Star on those classed as Jews the evaluation of the same events by another gentile, Pius István Zimándi (1909-1973). Zimándi was a member of the 
Vasvári, Louise O. "The Yellow Star and Everyday Life under Exceptional Circumstances: Diaries of 1944-1945 Budapest." Hungarian Cultural Studies. e-Journal of the American Hungarian Educators Association, Volume 9 (2016) DOI: 10.5195/ahea.2016.260

Premonstratensian religious order and a literary scholar, whose diary from March 19, 1944 to March 1945 has also only recently appeared. The diary, which I am unable to treat here in detail, is particularly interesting in that it represents the atmosphere and opinions of a segment of the intellectual Christian middle class. On the day of the csillag premierje ['the star's premiere'], as we saw above that persecuted Jewish "Margit" ironically referred to it, Zimándi expresses his surprise at realizing how many Jews lived in Budapest. By his observation of passers-by in downtown Budapest on that first day he judged that one in four were Jews. He was, in fact, just about right in his counting since the Jewish Laws affected twenty to twenty five percent of the Budapest population:

I would never have believed that there are so many Jews in Pest. I kept on counting them at the street crossings and among those crossing at once there were regularly eight to ten Jews. It's as if every fourth person in Pest is a Jew.

\begin{abstract}
[Hanem hogy annyi zsidó van Pesten, sose hittem volna. Átjáróknál számolgatom is öket. A sarkokon az egyszerre átmenök közül rendesen 8-10 volt a zsidó. Mintha minden negyedik ember zsidó volna Pesten.]
\end{abstract}

Klára Szebeny, Karafiath Jenőné (1920-2015) started her letter-diary on December 26, 1944 and wrote until June 17, 1945, during which time she wrote almost daily in the form of letters to her husband, whose whereabouts on the front she did not know, but hoped that he would eventually return. He did survive and was able to read the letters after he was freed as an American prisoner of war. Forty years later she typed the letters into a computer and printed them out for her family. She stated that the original manuscript is extant and that she has added nothing but only left out some bits. In her introduction to her letter-diary Szebeny wrote that she had wanted to show what the war was like and how she, then a twenty-four year old mother with two very small children, three-year old András and one-year old Judit, and her family survived in their house on Rozsadomb, where twelve to fourteen people, including two maids, lived mostly in hiding from the bombing in an eleven square meter small basement laundry room. Another twenty years after she had typed up her diary, her son, András Szekfü (Karafiath) put it up on a Facebook site in serial fashion so that readers would have a sense of reading it as an actual diary, the way it was written (see on Facebook, Családi története - Ex 103 el nem küldött levél Budapest ostromárol). Interestingly, Szekfü is following a present-day movement of individuals posting diaries and letters of World War II from their own family archives as historical blogs, served up in a day-to-day form, although most such archives feature letters from soldiers on the frontlines (http://ww2today.com/featured/diaries-of-world-war-ii). Sebényi's Facebook archive is also accompanied by many striking photos, as well as, from November 2015, very interesting short folkloric vignettes about life in Hungary during her youth, which she wrote into the computer at age ninety; the collection is titled "Gyerekkorom messzeringó világa" ['The WideSweeping World of My Childhood'], after a verse from the patriotic elegy "Nem tudhatom" ['I Can't Know'] written by Miklós Radnóti in January, 1944, at a time when those verses had a much more sinister connotation.

Although Szebeny died in October 2015, she did live to see her diary published earlier that year in book form as 103 el nem küldött levél Budapest ostromárol ['One Hundred and 
Vasvári, Louise O. "The Yellow Star and Everyday Life under Exceptional Circumstances: Diaries of 1944-1945 Budapest." Hungarian Cultural Studies. e-Journal of the American Hungarian Educators Association, Volume 9 (2016) DOI: 10.5195/ahea.2016.260

Three Unsent Letters about the Siege of Budapest']. She writes that she decided not to flee because it would have been too hard to do so with her small children and that her husband, Jenö, could move more easily on his own. She also was able to obtain a Swedish Schutzpass, a fact we do not hear much about in the case of Christians, but she needed protection because of a rumor that the Germans would take hostages from members of political families and her father-in-law was a retired minister, and her own grandfather had also been active in political life. Like Dévényiné, Klára Szebeny complains in her diary that she had to become the head of the household and be decisive making all the decisions and keeping a cheerful countenance for her family; it is only at night she can cry and also write in her diary as an escape: hogy jól kipanaszkodhassam magamat ['so that I could really get all that complaining out']. In her daily entries she complains about trying to maintain basic cleanliness for her children and about ever dwindling food supplies. During a bombing on January 23, 1945 most of her house is burnt down and while her belongings are salvaged they are immediately in part stolen, exemplifying what Lévai wrote about everyone ending up stealing from everyone else. She writes how on January 30 the Russians reach them and all the women put on scarves and try to look old but that, so far at least, the Russians were behaving all right, although she realizes that later they may not, but for now some just wanted to trade sugar for watches. Throughout her ordeal Szebeny expresses her love and amazing patience for her children, although in the end, in the months after the war, she will be forced to leave them for a while in a kind of orphanage so that they are fed and so that she can try to work where she gets no pay but at least free soup.

Szebeny's diary, although essentially made up of minute daily events, includes many significant minor and major comments. For example, she mentions an older man in their bunker, who even in their desperate situation could only think of his stomach and expected his wife to continue to serve him continually. She also writes interestingly of the days after liberation on February 13, about what she sees on the streets as she traverses Budapest on foot, and how the city begins to come alive, with more and more stores beginning to open up again by April. Sadly, in spite of the charm and warmth of the diarist's writing style it cannot escape a reader today how different her concept of the war inevitably was than that of Dévényiné and Lévai, who from March 1944 were, together with their families, in mortal danger every moment. Szebény can write without irony in December 1944 that her family was able to vacation from March 1944 through the whole summer and fall in their Balaton house: "this summer still passed under almost peacetime conditions, even if with troubled portent for the future" [ez a nyár meg majdnem békebeli körülmények, de bajos elöjelekkel telt el]. The family still held a festive wedding and they spent a beautiful autumn in their summer house on the Balaton, where they were still able to bathe on October 7. They finally close their house and return to Budapest in November and by December, while still listening to nice music from Vienna on their radio, they can hear the front approaching because of the faraway sounds of anti-aircraft fire. Soon there is no more radio transmission, no newspapers, and they cannot even go upstairs to the house to cook and must spend all their time in the bunker; it is at this time that she starts writing her diary. In the diary she, in effect, says nothing, even in hindsight, about any events of 1944, except that for a while people wanted to believe in the myth of the reputed "secret weapon"-perhaps emanating ultimately from the Germans' secret attempt to develop an atom bomb-that would win the war. Here it is worthwhile to contrast Dévényiné's June 17 reaction in real time to this secret weapon rumor that was much touted in the newspapers: 
Vasvári, Louise O. "The Yellow Star and Everyday Life under Exceptional Circumstances: Diaries of 1944-1945

Budapest." Hungarian Cultural Studies. e-Journal of the American Hungarian Educators Association, Volume 9

(2016) DOI: 10.5195/ahea.2016.260

The newspapers are full of news about the Germans' new weapon. Today the Vértes couple were here and Vértes kept on glorifying the weapon: he said that with this he believed that the Germans will win the war. It's some kind of flying rocket, which they used to bomb London (73).

[Az újságok tele vannak a németek új fegyverével. Ma Vértesék is itt voltak és Vértes is csak a fegyvert dicsöítette: azt mondta, ezzel elhiszi hogy megnyerik a németek a háborút. Valami repülö rakéta, Londont bombázták vele.]

At one point, in the context of the Swedish Schutzpass Szebeny obtained she adds that Swedish protection brought salvation to many szerencsétlen ['unfortunate'] Jews but that it remained to be seen whether the same letter of protection would help her with the Russians.

Since I have been writing about diaries written about Budapest in 1944-45 it is necessary to mention, if only briefly, the also only recently published diary of the wife of Miklós Horthy, born Magdolna Purgly (1881-1959). Mrs. Horthy starts her diary only on November 6, 1944, three weeks after the family was arrested by the Gestapo and sent to Bavaria, where they were held under house arrest, and ends it in December 1945. Her grandson, István Horthy Sharif, in whose garage in South England the diary was found, says that he was unaware of its existence as his grandmother, with whom he lived until age seventeen, never talked about having written one. The diary is totally silent about everything that happened in Hungary before November and is focused only on the family's daily routines and terrible tedium and on the pain of a total lack of information about home and about Miklós Horthy Jr., or 'Niki,' who was kept at the time by the Germans in Mauthausen. He had been kidnapped with the threat that he would be killed unless Horthy abdicated in favor of Szálasi, which is why he then did. As Horthy's grandson says, his grandmother was clearly very careful about not writing anything that could get them into trouble, but she did occasionally make personal emotional observations, such as how sorry she was to learn that Mussolini had been killed, as he had been a true friend of her husband. Towards the end of her slim diary she also allows herself a kind of declaration of love to her absent husband, lamenting how hard it was to be separated from him for over five months, "when I have lived my whole life only for you and only because of you. And precisely now I can't share these difficult times with you" [mikor egész életemen keresztül csak neked és csak érted éltem. És pont most nem oszthatom meg veled ezeket a nehéz időket].

All these diaries present the wartime history of Hungary in 1944-45 not as official history but as experienced, seen, and described from the point of view of people trying to lead their existential daily life; just the same, these diaries give us glimpses of big historical events such as the March 19, 1944 German occupation of Hungary, or the December 25, 1944 Russian encircling of Budapest, that impel the diarists to start writing. By reframing history through their personal and family experience and by recounting everyday events left out of official history the diarists provide not merely source material for history but also an alternative way of narrating the past, conveying both the factual events and experiences of the war and their own individual suffering and coping with catastrophe. 
Vasvári, Louise O. "The Yellow Star and Everyday Life under Exceptional Circumstances: Diaries of 1944-1945

Budapest." Hungarian Cultural Studies. e-Journal of the American Hungarian Educators Association, Volume 9

(2016) DOI: 10.5195/ahea.2016.260

\section{Works Cited}

Casey, Stephen Posted 2005. "My Story, 1944-45, Hungary to Buchenwald, Mauthausen, and Back.” http://isurvived.org/Survivors_Folder/Stephen_Casey-hungarian.html

Fulbrook, Mary, and Ulinka Rublack. 2010. "In Relation: The 'Social Self' and Ego Documents." German History 28/3: 263-272.

Herzog, Esther. 2009. "Introduction: Studying the Holocaust as a Feminist." Life, Death and Sacrifice. Women and Family in the Holocaust. Ed. Esther Herzog. NY: Gefen: 1-18.

Hogan, Rebecca. 2008. "Engendered Autobiographies: The Diary as A Feminine Form." Prose Studies: History, Theory, Criticism 14/2: 95-107.

Horthy Miklósné. 2015. Napló 1944-45 ['Diary 1944-45’]. Budapest: Libri.

Huff, Cynthia A., and Suzanne L. Bunkers. 1996. "Issues in Studying Women's Diaries. A Theoretical and Critical Introduction." Inscribing the Daily: Critical Essays on Women's Diaries. Eds. Cynthia A. Huff and Suzanne L. Bunkers. Amhert: U of Massachusetts P: 1-20.

Huhák, Helena, András Szécsényi, and Erika Szívós, eds. 2015. Kismama sárga csillaggal: egy fiatalasszony naplója a német megszállastol 1945 juliusáig ['Mother-in-Waiting With Yellow Star: The Diary of a Young Married Woman From the Germany Occupation to July 1945']. Budapest: Jaffa Kiadó.

Kaplan, Marion A. 1998. Between Dignity and Despair: Jewish Life in Nazi Germany. Oxford: Oxford UP.

Kunt, Gergely. 2014. "Ironic Narrative Agency as a Method of Coping with Trauma in the Diary-Memoir of Margit K, a Female Holocaust Survivor." Hungarian Cultural Studies 7 http://ahea.pitt.edu DOI: 10.5195/ahea.2016.230

Laczó, Ferenc. 2015. “The Foundational Dilemmas of Jenő Lévai: On the Birth of Hungarian Holocaust Historiography in the 1940s." Holocaust Studies 21/2: 1-27.

Lang, Berel. 2005. Interpretation, Misinterpretation and the Claims of History. Bloomington: Indiana UP.

Lévai, Jenő. "Csak ember kezébe ne essem én...” - Deportácio, télach, Schutzpass. Napló, 19441945 ["That I Should not Fall into the Hands of My Fellow Man: Deportation, Leaving, Letter of Protection ']. Ed. János Dési. Budapest: Múlt és Jövő, 2016.

LoBello, Maya. 2016. “The Holocaust Journal of Miksa Fenyö.” Hungarian Cultural Studies 9 http://ahea.pitt.edu DOI: 10.5195/ahea.2016.230

Lőwenstein, Enikő. 2016. "Női hangon megelevendő történelem. Könyvajánló: Budapesti háborus naplók" http://mandarchiv.hu/cikk/5391/Noi_hangon_megelevenedo_tortenelem

Mádi, Mária. 2015. Diaries. Manuscript, US Holocaust Memorial Museum http://collections.ushmm.org/search/catalog/irn50967

Ofer, Dalia. 2011. "Gender: Writing Women, Writing the Holocaust." Writing the Holocaust. Eds. Jean-Marc Dreyfus and Daniel Langton. London: Bloomsbury Academic: 7-25.

Ofer, Dalia. 2008. "Motherhood under Siege." Life, Death and Sacrifice: Women and Family in the Holocaust. Ed. Esther Hertzog. Jerusalem: Geffen: 41-67.

Popkin, Jeremy D. 2005. History, Historians, and Autobiography. Chicago: U of Chicago P. 
Vasvári, Louise O. "The Yellow Star and Everyday Life under Exceptional Circumstances: Diaries of 1944-1945

Budapest." Hungarian Cultural Studies. e-Journal of the American Hungarian Educators Association, Volume 9 (2016) DOI: 10.5195/ahea.2016.260

Ruane, Michael E. 2014. "Defiant Hungarian Doctor Hid Jewish Boy as Nazis Scoured Budapest during Holocaust." The Washington Post, November 29.

https://www.washingtonpost.com/local/defiant-hungarian-doctor-hid-jewish-boy-asnazis-scoured-budapest-during-holocaust/2014/11/29/92932f56-68f1-11e4-a31c$77759 \mathrm{fcleacc}$ story.html

Szabó, Borbála. 1983. Budapesti napló: 1944 november-1945 január ['Budapest Diary’]. Budapest: Magvetö

Szebeny, Klára. 2015. 103 el nem küldött levél Budapest ostromárol ['103 Unsent Letters from the Siege of Budapest']. Budapest: Gondolat Kiadó \& www.facebook.com/sdfgbcfklgk/

Szívós, Erika. 2014. "Kismama sárga csillaggal: egy fiatalasszony naplója a német megszállástol 1945 juliusig" ['Mother in Waiting With Yellow Star: The Diary of a Young Married Woman From the Germany Occupation to July 1945']. http://holocaust.archivportal.hu/sites/default/files/essay/doc/szivos_erika_kismama_sarga csillaggal.pdf

Vasvári, Louise O. 2014. "Hungarian Women's Life Writing in the Context of the Nation's Divided Social Memory, 1944-2014.” Hungarian Cultural Studies 7: 55-81 http://dx.doi.org/10.5195/ahea.2014.139. In Hungarian: "Magyar nők a holokausztéletirásai a megosztott nemzeti emlékezet kontextusában, 1944-2014.” Múlt és Jövö 25/3 (2014): 64-84.

Weitzman, Lenore L., and Dalie Ofer. 2001. "Women in the Holocaust: Theoretical Foundations for a Gendered Analysis of the Holocaust." Women in the Holocaust: Responses, Insights and Perspectives. Eds. Lenore J. Weitzman and Dalia Ofer. Merrion Station: Merion Westfield Press International: 1-34.

Zimandi, Pius István. 2015. Egyév története naplójegyzetekben (1944. március-1945. március). Budapest: Magvető. 